\title{
A bal kamrai relaxáció a túlélés független prediktora hipertrófiás cardiomyopathiában
}

\author{
Vilmányi Gábor oh., Molnár Fanni oh., Tóth Levente, Simor Tamás, Faludi Réka
}

Pécsi Tudományegyetem, Klinikai Központ, Szívgyógyászati Klinika, Pécs

Levelezési cím: Dr. Faludi Réka, 7624 Pécs, Ifjúság u. 13., E-mail: faludi.reka@pte.hu

\begin{abstract}
Bevezetés: A hipertrófiás cardiomyopathia $(\mathrm{HCM})$ a hirtelen szívhalál és a krónikus szívelégtelenség kockázatát hordozó genetikai betegség. Munkánk célja volt megvizsgálni a különböző echokardiográfiás és szív MR-paraméterek valamint az N-terminális B-típusú nátriuretikus peptid (NT-proBNP) prediktív erejét a betegség prognózisának meghatározásában.

Betegek, módszerek: Kutatásunkba 39 HCM-es beteget (48_14 év) vontunk be, akiknél 2003-2005 között echokardiográfiás és sziv MR-vizsgálatok, valamint NT-proBNP-szint meghatározás történt. Echokardiográfiával a kiáramlási grádiens mellett megvizsgáltuk a transmitralis flow értékeit (E, A, DT, IVRT). Szöveti Doppler segítségével szisztolés (s), koradiasztolés (e') és késődiaszolés (a') longitudinális sebességeket mértünk a mitralis anuluson laterálisan és szeptálisan, E/e' arányt számoltunk. 2D Simpson módszerrel meghatároztuk a bal pitvari volumeneket $\left(\mathrm{V}_{\max }, \mathrm{V}_{\min }, \mathrm{V}_{\mathrm{p}}\right)$. Szív MR-rel a bal kamrai ejekciós frakció és a maximális falvastagság mellett meghatároztuk a bal kamrai volumeneket és izomtömeget. Az utóbbi MR-paramétereket és a pitvari volumenértékeket testfelszínre normalizáltuk. A betegek túlélését átlagosan 12 év után vizsgáltuk meg. Mivel néhány esetben a halálok nem volt egyértelműen tisztázható, így az összhalálozást vizsgáltuk.
\end{abstract}

Eredmények: A 12,7士0,5 év követési idő alatt $14(35,9 \%)$ haláleset történt. Azokat a paramétereket, amelyek az egyszeres Cox-vizsgálat során $p<0,1$ szignifikanciát mutattak (laterális e', E/laterális e', $V_{\min }$ index, InNT-proBNP), valamint az életkort többváltozós Cox-regressziós egyenletbe rendeztük. Ez alapján a laterális e' bizonyult a halálozás egyetlen független prediktorának: $\mathrm{HR}(95 \% \mathrm{Cl})=0,702(0,528-0,933) ; p=0,015$. $R O C$-analízis alapján a laterális e' $<7,7 \mathrm{~cm} / \mathrm{s}$ érték bizonyult az összhalálozás legerösebb prediktorának (szenzitivitás $=76,9 \%$, specificitás $=76,0 \%$, AUC $=0,768$ ).

Következtetések: A bal kamrai relaxáció jellemzésére használt laterális e' jól használható paraméter lehet a betegség progressziójának követésére és a prognózis meghatározására HCM-ben.

Kulcsszavak: hipertrófiás cardiomyopathia, túlélés, echokardiográfia, szöveti Doppler, bal kamrai relaxáció

\section{Left ventricular relaxation is an independent predictor of the survival in hypertrophic cardiomyopathy}

Background: Hypertrophic cardiomyopathy (HCM) is a genetically-determined disease with a high risk for sudden cardiac death or chronic heart failure. Our aim was to investigate the long term prognostic value of various echocardiographic and cardiac MRI parameters as well as N-terminal B-type natriuretic peptide (NT-proBNP) levels in HCM patients. Patients and methods: $39 \mathrm{HCM}$ patients (48 14 years) were enrolled into the study. They underwent echocardiography and cardiac MRI between 2003-2005. NT-proBNP levels were measured in parallel. Echocardiography was used to measure left ventricular outflow gradient and the parameters of the transmitral flow (E, A, DT, IVRT). Tissue Doppler technique was used to obtain systolic (s), early- (e') and late-diastolic (a') velocities on the lateral and septal mitral annulus. E/e' ratio was calculated. Left atrial volumes $\left(\mathrm{V}_{\max }, \mathrm{V}_{\min }, \mathrm{V}_{\mathrm{f}}\right)$ were measured by using $2 \mathrm{D}$ Simpson method. In addition to the left ventricular volumes and mass, left ventricular ejection fraction and maximal left ventricular wall thickness were measured by cardiac MRI. Left ventricular and atrial volumes as well as mass were normalized to body surface area. Survival was assessed after 12 years. Since in some cases the cause of death was unknown, all-cause mortality was chosen as outcome. Results: During the follow-up period of $12.7 \pm 0.5$ years, 14 patients $(35.9 \%)$ died. By entering those variables (lateral e', E/lateral e', $V_{\min }$ index, InNT-proBNP) with $p$-values $<0.1$ in the univariate Cox regression analysis, multivariate Cox regression analysis was performed. Age was also included into the model. Lateral e' was proved to be the only independent predictor of mortality: $\mathrm{HR}(95 \% \mathrm{Cl}): 0.702(0.528-0.933) ; p=0.015$. Using ROC analysis, lateral $\mathrm{e}^{\prime}<7.7 \mathrm{~cm} / \mathrm{s}$ was the strongest predictors of the mortality (sensitivity $=76.9 \%$, specificity $=76.0 \%, A U C=0.768$ ).

Conclusion: Lateral e' - the parameter characterizing left ventricular relaxation - may be useful in the risk stratification and prognosis assessment in HCM patients.

Keywords: hypertrophic cardiomyopathy, survival, echocardiography, tissue Doppler imaging, left ventricular relaxation 


\section{Bevezetés}

Hipertrófiás cardiomyopathia (HCM) a miokardiális hipertrófiával és diasztolés telődési zavarral járó primer szívizombetegségek összefoglaló neve, amelyek hátterében különböző genetikai eltérések állhatnak, ám leggyakoribbak a szarkomer fehérjéket kódoló géneket érintő mutációk. A betegség ismert tünetei - syncope, anginaszerủ mellkasi fájdalom, hirtelen szívhalál - jellemzően fiatal felnőttkorban jelentkeznek. Ugyanakkor hosszú távon megtartott ejekciós frakcióval járó szívelégtelenség alakul ki a betegek jelentős részénél (1). A HCM-es populáció éves mortalitása $1-2 \%$. A primer és szekunder prevenciós ICD-implantáció bevezetése jelentősen csökkentette a HCM-mel kapcsolatos aritmia-halálozást, így előtérbe került a szívelégtelenség okozta halálozás vizsgálatának jelentősége ebben a populációban. Ennek ellenére a jelenlegi nemzetközi ajánlások elsősorban a hirtelen halál kérdésére fókuszálnak, és nem említik érdemben a szívelégtelenség problémakörét (2-5).

A kérdés súlyához képest kevés adat áll rendelkezésre azzal kapcsolatban, hogy a bal kamrai relaxáció és töltőnyomás jellegzetes echokardiográfiás paraméterei alkalmasak-e a HCM-es betegek prognózisának becslésére. Kutatásunk célja ezért egy olyan paraméter azonosítása volt, amely a rutinszerüen használt diagnosztikus módszerekkel könnyen vizsgálható, és jól korrelál a betegség prognózisával. Így a bal szívfél méretét és funkcióját jellemző echokardiográfiás és szív MR-paraméterek, valamint a plazma $\mathrm{N}$-terminális $\mathrm{B}$-típusú nátriuretikus peptid- (NT-proBNP) szintek korrelációját vizsgáltuk a HCM-es populáció túlélésével öszszefüggésben.

\section{Betegek, módszerek}

Munkánk során a Pécsi Tudományegyetem Szívgyógyászati Klinikájának HCM-es adatbázisát vettük alapul. Retrospektív kutatásunkba 39 konszekutív beteg került bevonásra, akiknél 2003 és 2005 között echokardiográfiás és szív MR-vizsgálat, valamint NT-proBNP-szint meghatározás történt. A csökkent bal kamrai szisztolés funkcióval $(55 \%$ alatti ejekciós frakció), pitvarfibrillációval, szignifikáns billentyübetegséggel, vagy mübillentyűvel rendelkező betegeket kizártuk a vizsgálatból.

A betegek túlélését 2016 novemberében vizsgáltuk meg. Követési időnek az echokardiográfiás vizsgálat és az utolsó klinikai megjelenés vagy a halálozás időpontja közötti intervallumot tekintettük. Az elhunytakról összegyüjtöttük a rendelkezésre álló orvosi dokumentációkat, valamint telefonon megkerestük a hozzátartozókat. Mivel a halál oka az esetek egy részében nem volt korrekten tisztázható, az összhalálozást választottuk a vizsgálat végpontjának.
Kutatásunk megfelelt a Helsinki Nyilatkozatban foglaltaknak, az intézményi etikai bizottság engedélyezte. Minden résztvevő beleegyező nyilatkozatot írt alá a képalkotó vizsgálatok megkezdése előtt.

\section{Echokardiográfia}

Az echokardiográfiás vizsgálatok ATL HDI 5000 (Philips Healthcare, Best, The Netherlands) készülékkel történtek. A kiáramlási csúcsgrádiens mértékét folyamatos hullámú Dopplerrel határoztuk meg. Megvizsgáltuk a transzmitralis flow értékeit: koradiasztolés $(E)$, késődiasztolés (A) sebességet és decelerációs időt (DT) mértünk. Kiszámoltuk az E/A arányt. Az izovolumetriás relaxációs időt (IVRT) folyamatos hullámú Dopplerrel mértük, az aortazáródási klikk és a mitralis beáramlási görbe kezdete között. Csúcsi négyüregủ nézetből pulzatilis szöveti Doppler segítségével szisztolés (s), koradiasztolés (e') és késődiasztolés (a') longitudinális csúcssebességeket mértünk a mitralis anulus magasságában laterálisan és szeptálisan. Laterális, szeptális és átlagos E/e' arányt számoltunk (6). Csúcsi négy-, illetve kétüregü nézetböl 2D Simpson-módszerrel bal pitvari volumeneket határoztunk meg a szívciklus jellegzetes fázisaiban: a maximális bal pitvari térfogatot $\left(V_{\max }\right)$ a mitralis billentyű nyílását megelőzően; a minimális pitvari térfogatot $\left(\mathrm{V}_{\text {min }}\right)$ a mitralis billentyủ záródását követően; a pitvari kontrakciót megelőző térfogat- $(V p)$ értéket a $P$-hullám kezdeténél olvastuk le. $A$ volumenértékeket testfelszínre normalizáltuk $\left(V_{\max }\right.$, $V_{\min }, V_{p}$ index) (7). Doppler és szöveti Doppler eredményeinket három, egymást követő mérés átlagából határoztuk meg.

\section{A bal kamrai diasztolés funkció értékelése} A HCM-es populációt bal kamrai diasztolés funkciójuk szerint csoportosítottuk, a legfrissebb ajánlás alapján. Normálrelaxáció: laterális $e^{\prime} \geq 10 \mathrm{~cm} / \mathrm{s}$, szeptális $e^{\prime} \geq 7$ $\mathrm{cm} / \mathrm{s}, E / A \geq 0,8, E / e^{\prime}<10$; károsodott relaxáció: laterális $e^{\prime}<10 \mathrm{~cm} / \mathrm{s}$, szeptális $e^{\prime}<7 \mathrm{~cm} / \mathrm{s}, E / A<0,8, E / e^{\prime}<10$; pszeudonormális mintázat: laterális e'<10 $\mathrm{cm} / \mathrm{s}$, szeptális e'<7 cm/s, E/A 0,8-2, E/e' 10-14; restriktív mintázat: laterális e'<10 cm/s, szeptális e' $<7 \mathrm{~cm} / \mathrm{s}, E / A>2, E / e^{\prime}>14$ (8).

\section{B-típusú nátriuretikus peptid- (NT-proBNP) szint mérés}

Az NT-proBNP-szint mérése immunoassay módszerrel (Roche Elecys teszt) történt. Az eredmények vizsgálatakor az alábbi normálértékeket vettük alapul: nőknél 50 éves korig $<153 \mathrm{pg} / \mathrm{ml}$, 50 éves kor felett $<334 \mathrm{pg} /$ $\mathrm{ml}$, míg férfiak esetében 50 éves korig $<88 \mathrm{pg} / \mathrm{ml}, 50$ éves kor felett $227 \mathrm{pg} / \mathrm{ml}$.

\section{Szív MR-vizsgálatok}

A szív MR-vizsgálatok 1,5 T Siemens Vision Plus, Siemens Avanto és GE Signa készülékek segítségével történtek. Bal kamrai izomtömeg, végszisztolés és végdi- 
asztolés volumen került meghatározásra. Az ily módon nyert paramétereket testfelszínre normalizáltuk. A bal kamra ejekciós frakcióját és a maximális falvastagságot is szív MR-vizsgálat segítségével határoztuk meg.

\section{Statisztikaî módszerek}

Eredményeinket átlagıstandard deviáció (SD) formátumban tüntettük fel. A csoportok összehasonlításához folytonos változóknál kétmintás t-próbát, illetve az NT-proBNP-értékek esetében Mann-Whitney-tesztet, míg a kategórikus változóknál khi-négyzet próbát használtunk. A vizsgált paraméterek túlélésre gyakorolt hatását egyszeres Cox-regresszióval vizsgáltuk. Az NT-proBNP nem mutatott normális eloszlást, ezért az értékeket természetes alapú logaritmussá (InNT-proBNP) alakítottuk. Azokat a paramétereket, amelyek ebben a vizsgálatban $p<0,1$ szignifikanciát mutattak, többszörös Cox-regreszsziós egyenletbe rendeztük (backward stepwise), meghatározandó a túlélés független prediktorait. A betegek életkorát szintén bevontuk a vizsgált paraméterek közé. A többszörös Cox-regressziós egyenletben szignifikánsnak bizonyuló paraméter esetében ROC-görbét készítettünk, majd meghatároztuk a lehető legmagasabb szenzitivitással és specificitással bíró cut-off értéket. Ennek mentén a vizsgált populációt két csoportra osztottuk. Végül Kaplan-Meier-görbét rajzoltunk fel és a két csoport túlélése közötti különbséget Mantel Cox log rank teszt segítségével vizsgáltuk. Vizsgálataink során $p<0,05$ értéket fogadtuk el szignifikánsnak. Adataink feldolgozását IBM SPSS 22 (IBM SPSS Inc., Chicago, Illinois, USA) programmal végeztük (1. ábra).

\section{Eredmények}

A $27(69,2 \%)$ férfi és 12 (30,8\%) nő átlagos életkora $48 \pm 14$ év volt az adatgyűjtés időpontjában. Két beteg esetében (5,1\%) koncentrikus balkamra-hipertrófiát állapítottunk meg, míg 37 betegnél (94,9\%) különböző kiterjedésű aszimmetrikus szeptum-hipertrófia volt jelen. Nyolc (20,5\%) beteg esetében detektáltunk $30 \mathrm{Hgmm}-\mathrm{t}$ meghaladó csúcsgrádiensű nyugalmi bal kamrai kiáramlási obstrukciót. Bal kamrai diasztolés funkciózavart 31 betegben $(79,5 \%)$, míg emelkedett töltőnyomásra utaló értékeket $22(56,4 \%)$ betegben találtunk. Az NT-proBNP-érték 30 beteg (76,9\%) esetében volt emelkedett. A betegek további paramétereit az 1. táblázatban foglaltuk össze.

A bevonáskor a betegek között nem volt ICD-hordozó. Hirtelen halál nem volt explorálható egyetlen beteg családi anamnézisében sem. Átlagosan 12,7士0,5 év követési idő után vizsgáltuk meg a betegek túlélését. A követési idő alatt összesen 14 (35,9\%) haláleset történt. Ez idő alatt két betegnél sebészi myectomia, két mitrális mübillentyü-beültetés, 4 esetben perkután koronária-angioplasztika, míg 3 betegnél ICD-beültetés történt, primer prevenciós indikációval. Egy betegnél bal kamrai assisst device került beültetésre.

Egyváltozós Cox-regressziós analízis alapján 4 változó bizonyult a halálozás szignifikáns prediktorának: laterális e', E/laterális e', $\mathrm{V}_{\min }$ index illetve InNT-proBNP. Többváltozós Cox-regressziós analízis alapján a fenti paraméterek közül a laterális e' bizonyult a halálozás egyetlen független prediktorának (HR: 0,702; 95\% Cl: 0,528-0,933; p=0,015) (2. táblázat).

ROC-görbe segítségével megállapítottuk, hogy $7,7 \mathrm{~cm} / \mathrm{s}$ az a laterális e' érték, ami a lehető legmagasabb szenzitivitással és specificitással képes megkülönböztetni a túlélő és elhunyt HCM-es populációt. A laterális e' paraméterhez tartozó $\mathrm{ROC}$-görbét valamint a $7,7 \mathrm{~cm} / \mathrm{s}-\mathrm{os}$ cut-off érték felhasználásával elkészített Kaplan-Meier túlélési görbét az 1. ábrán, míg a két alcsoport jellemző vizsgálati eredményeit az 1 . táblázatban mutatjuk be.
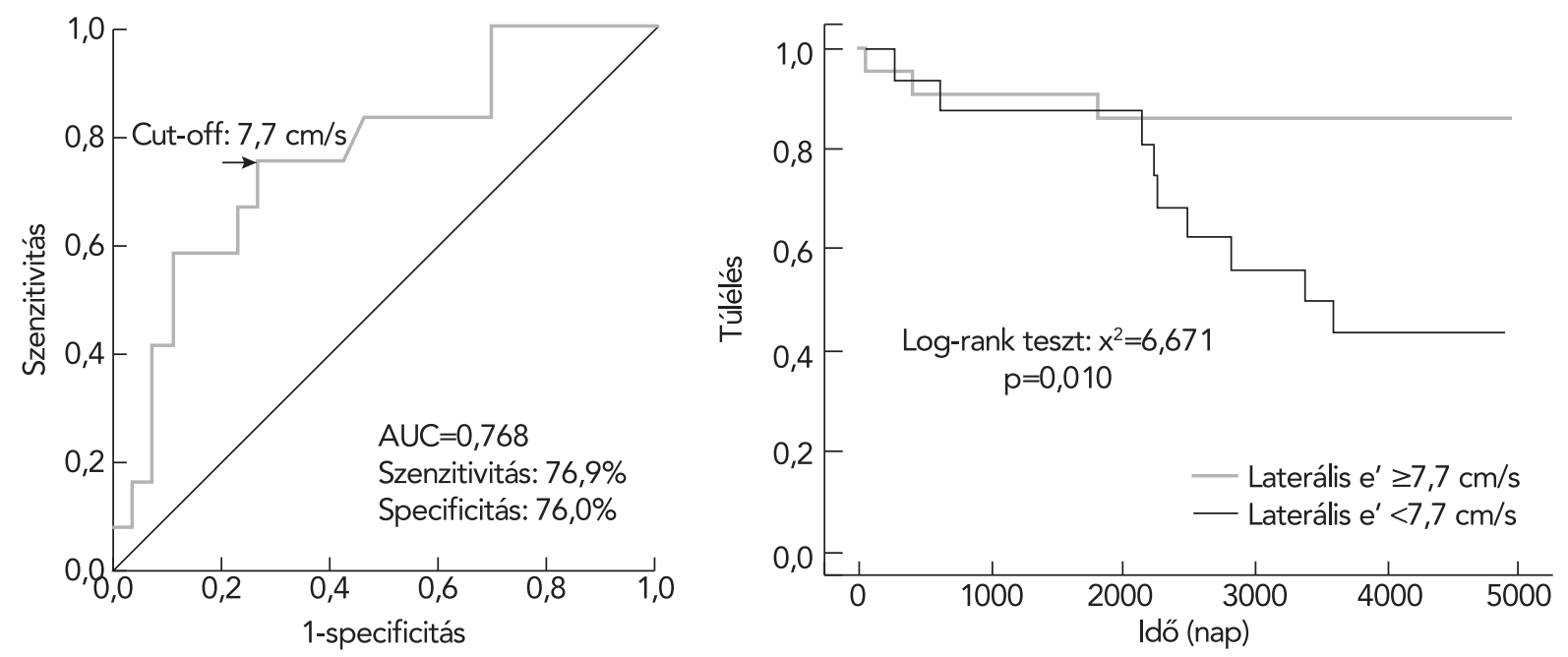

1. ÁBRA. ROC-görbe (A) és Kaplan-Meier túlélési görbe (B) demonstrálja a laterális e' érték prognosztikus szerepét a HCM-es populáció túlélésével kapcsolatban 
1. TÁBLÁZAT. A teljes HCM-es populáció és a különböző prognózisú csoportok klinikai adatai és vizsgálati paraméterei. A szignifikáns p-értékeket bold betűtípussal jelöltük

\section{Vizsgált paraméter}

Teljes populáció $(n=39)$

\section{Laterális e'}

$\geq 7,7 \mathrm{~cm} / \mathrm{s}(\mathrm{n}=21) \quad<7,7 \mathrm{~cm} / \mathrm{s}(\mathrm{n}=18)$
$55 \pm 15$

$7(38,9 \%)$

$1,9 \pm 0,2$

$11(61,1 \%)$

$6(28,6 \%)$
$2,0 \pm 0,3$
$3(14,3 \%)$

$30(76,9 \%)$

$9(23,1 \%)$

$23,9 \pm 31,0$

$79,8 \pm 22,9$

$71,1 \pm 26,7$

$212,2 \pm 66,1$

$107,8 \pm 26,5$

$1,2 \pm 0,5$

E/A

Laterális $\mathrm{s}(\mathrm{cm} / \mathrm{s})$

Laterális e' $(\mathrm{cm} / \mathrm{s})$

Laterális a' $(\mathrm{cm} / \mathrm{s})$

Szeptális $\mathrm{s}(\mathrm{cm} / \mathrm{s})$

Szeptális e' $(\mathrm{cm} / \mathrm{s})$

Szeptális a' $(\mathrm{cm} / \mathrm{s})$

E/laterális e'

E/szeptális e'

$V_{\max }$ index $\left(\mathrm{ml} / \mathrm{m}^{2}\right)$

$\mathrm{V}_{\text {min }}$ index $\left(\mathrm{ml} / \mathrm{m}^{2}\right)$

$\mathrm{V}_{\mathrm{p}}$ index $\left(\mathrm{ml} / \mathrm{m}^{2}\right)$

Bal kamrai diasztolés funkció n (\%)

- normális

- károsodott relaxáció

- pszeudonormális

- restriktív

\section{Szív MR-paraméterek}

Maximális falvastagság $(\mathrm{mm})$

Izomtömeg-index $\left(\mathrm{g} / \mathrm{m}^{2}\right)$

Végszisztolés térfogat index $\left(\mathrm{ml} / \mathrm{m}^{2}\right)$

Végdiasztolés térfogat index $\left(\mathrm{ml} / \mathrm{m}^{2}\right)$

Verőtérfogat index $\left(\mathrm{ml} / \mathrm{m}^{2}\right)$

Ejekciós frakció (\%)

NT-proBNP (pg/ml)
$7,8 \pm 2,3$

$8,5 \pm 2,8$

$9,4 \pm 2,4$

$6,9 \pm 1,8$

$6,0 \pm 1,6$

$8,2 \pm 2,5$

$10,5 \pm 5,0$

$14,2 \pm 5,7$

$11,9 \pm 5,1$

$44,3 \pm 23,0$

$24,3 \pm 14,2$

$33,7 \pm 18,3$

$8(20,5 \%)$
$9(23,1 \%)$
$18(46,2 \%)$
$4(10,1 \%)$

$4(10,1 \%)$
E/átlag e'
$17(80,9 \%)$

$4(19,0 \%)$

$17,3 \pm 16,1$

$78,3 \pm 17,8$

$65,8 \pm 22,1$

$195,2 \pm 47,6$

$104,6 \pm 27,4$

$1,3 \pm 0,5$

$8,6 \pm 2,2$

$10,3 \pm 2,4$

$9,6 \pm 1,9$

$7,6 \pm 1,7$

$6,8 \pm 1,5$

$9,0 \pm 2,3$

$8,0 \pm 2,6$

$11,9 \pm 3,4$

$9,4 \pm 2,5$

$34,3 \pm 17,5$

$18,7 \pm 11,2$

$25,4 \pm 13,5$

$8(38,1 \%)$

$5(23,8 \%)$

$7(33,3 \%)$

$1(4,8 \%)$
$13(72,2 \%)$

$5(27,8 \%)$

$31,60 \pm 41,5$

$81,7 \pm 28,5$

$77,7 \pm 31,0$

$235,4 \pm 79,4$

$111,7 \pm 25,6$

$1,2 \pm 0,5$

$6,9 \pm 2,1$

$6,2 \pm 1,2$

$9,0 \pm 2,9$

$6,1 \pm 1,7$

$5,0 \pm 1,0$

$7,1 \pm 2,2$

$13,6 \pm 5,6$

$17,2 \pm 6,7$

$15,2 \pm 5,8$

$56,0 \pm 23,5$

$30,9 \pm 14,8$

$43,5 \pm 18,6$

0

$4(22,2 \%)$

$11(61,1 \%)$

$3(16,7 \%)$

0,519

0,183

0,651

0,178

0,061

0,421

0,420

0,020

0,000

0,434

0,010

0,000

0,014

0,000

0,004

0,000

0,002

0,006

0,001

0,020

\begin{tabular}{|c|c|c|c|}
\hline $24,7 \pm 5,7$ & $23,1 \pm 4,7$ & $26,5 \pm 6,4$ & 0,068 \\
\hline $119,5 \pm 39,8$ & $111,8 \pm 15,2$ & $129,3 \pm 44,3$ & 0,206 \\
\hline $17,6 \pm 8,3$ & $17,9 \pm 6,7$ & $17,2 \pm 10,3$ & 0,081 \\
\hline $62,5 \pm 18,5$ & $63,5 \pm 19,5$ & $61,3 \pm 17,8$ & 0,742 \\
\hline $45,0 \pm 13,1$ & $45,6 \pm 15,0$ & $44,1 \pm 10,4$ & 0,753 \\
\hline $70,9 \pm 8,5$ & $70,8 \pm 6,8$ & $70,9 \pm 10,3$ & 0,995 \\
\hline $1256 \pm 1989$ & $575 \pm 638$ & $2012 \pm 2646$ & $\mathbf{0 , 0 2 2}$ \\
\hline
\end{tabular}

p-érték

0,007

0,632

0,545

0,002

\section{Megbeszélés}

A két csoport szignifikánsan különbözik a bal kamrai diasztolés funkció lényegében minden paramétere, illetve az NT-proBNP-szint tekintetében. Ugyanakkor a szív MR segítségével vizsgált morfológiai paraméterek hasonlóak voltak a két csoportban.
Az irodalmi adatok szerint a HCM-es betegek több mint felében detektálható bal kamrai diasztolés funkciózavar. A betegek számottevő hányadában fejlődik ki 
2. TÁBLÁZAT. A vizsgált paraméterek hatása a túlélésre Cox-regressziós analízis alapján. A szignifikáns összefüggéseket bold betűtípussal jelöltük

\begin{tabular}{|l|c|c|c|c|} 
& \multicolumn{2}{|c|}{ Egyváltozós Cox-regresszió } & \multicolumn{2}{|c|}{ Többváltozós Cox-regresszió } \\
\hline & HR (95\% Cl) & p-érték & HR (95\% CI) & p-érték \\
\hline Életkor (év) & $1,029(0,987-1,073)$ & 0,184 & \\
\hline Laterális e' $(\mathrm{cm} / \mathrm{s})$ & $0,696(0,521-0,930)$ & $\mathbf{0 , 0 1 4}$ & $0,702(0,528-0,933)$ & $\mathbf{0 , 0 1 5}$ \\
\hline E/laterális e' & $1,081(0,093-1,178)$ & $\mathbf{0 , 0 7 3}$ & \\
\hline $\mathrm{V}_{\min }$ index $\left(\mathrm{ml} / \mathrm{m}^{2}\right)$ & $1,046(1,012-1,081)$ & $\mathbf{0 , 0 0 7}$ & \\
\hline InNT-proBNP $(\mathrm{pg} / \mathrm{ml})$ & $1,506(0,973-2,332)$ & $\mathbf{0 , 0 6 6}$ & \\
\hline
\end{tabular}

megtartott ejekciós frakcióval járó szívelégtelenség is az évek során. Ez felelős a betegek panaszainak jelentős részéért: csökkent terhelhetőség, effort diszpnoe, végül manifeszt szívelégtelenség (1-5). Érdekes módon az irodalomban a hirtelen halál problémaköre kap nagyobb hangsúlyt, míg kevés adat áll rendelkezésre azzal kapcsolatban, hogy a bal kamrai relaxáció és töltőnyomás jellegzetes paraméterei alkalmasak-e a HCM-es betegek prognózisának becslésére. Kutatásunk során ezért egy olyan morfológiai vagy funkcionális paramétert kerestünk, amely a rutinszerüen használt diagnosztikus módszerekkel könnyen vizsgálható és jól korrelál a betegség prognózisával.

A szöveti Doppler-technika bevezetése forradalmasította a bal kamrai diasztolés funkciózavar vizsgálatát (8). Ez a fajta képalkotás alkalmas többek között a HCM-es betegek kiszűrésére már a tünetek vagy a hipertrófia megjelenését megelőzően is, függetlenül a kiváltó génmutációtól $(9,10)$, és természetesen lehetővé teszi a bal kamrai diasztolés funkció vizsgálatát ebben a kórképben is (11).

A szöveti Doppler-paraméterek prognosztikus erejét már több tanulmány is vizsgálta HCM-ben. Kitaoka és munkatársai kutatásában az E/szeptális e' paraméter bizonyult a kombinált végpont (HCM-hez kapcsolható halálozás, új keletü pitvarfibrilláció, malignus kamrai ritmuszavar, szívelégtelenség miatti hospitalizáció) független prediktorának (12). Gyermekkorú HCM-esek körében végzett, hasonló felépítésű vizsgálatuk során McMahon és munkacsoportja is hasonló eredményre jutott (13). Saját eredményeink ezzel szemben a laterális e' segítségével kiszámított E/e' prediktív szerepét igazolták, többszörös Cox-regressziós analízisben azonban ez sem bizonyult a halálozás független prediktorának, annak ellenére sem, hogy az E/e' értékek jellemzően emelkedettek voltak az általunk vizsgált populációban is. Munkánkban a vizsgált szöveti Doppler-paraméterek közül a laterális e' érték bizonyult az összmortalitás egyedüli független prediktorának. Már Nagueh és munkatársai, később mások is rávilágítottak arra, hogy dominálóan szeptális lokalizációjú hipertrófiával járó HCM esetében a szeptális anuluson mért értékek kevésbé reprodukálhatók, és elsősorban a regionális miokardiális funkciót tükrözik $(14,15)$. Ugyanakkor ismert, hogy a HCM-hez vezető eltérések celluláris és szubcellulá- ris szinten a myocardium minden sejtét érintik $(14,16)$. Így annak ellenére, hogy a laterális fal hipertrófiája kevésbé kifejezett aszimmetrikus szeptumhipertrófia esetén, a laterális mitralis anuluson mért e' érték tükrözi megbízhatóbban a globális bal kamrai relaxációs zavar mértékét (2. ábra). Eredményeink megerősítik, hogy szeptális lokalizációjú hipertrófia esetén célszerübb a laterális anuluson mért szöveti Doppler-paramétereket vizsgálni, mert a szeptálisan mért értékek elveszíthetik globális jellegüket.

A nátriuretikus peptidek (BNP, NT-proBNP) szérumszintjének vizsgálata mind a szisztolés típusú, mind a

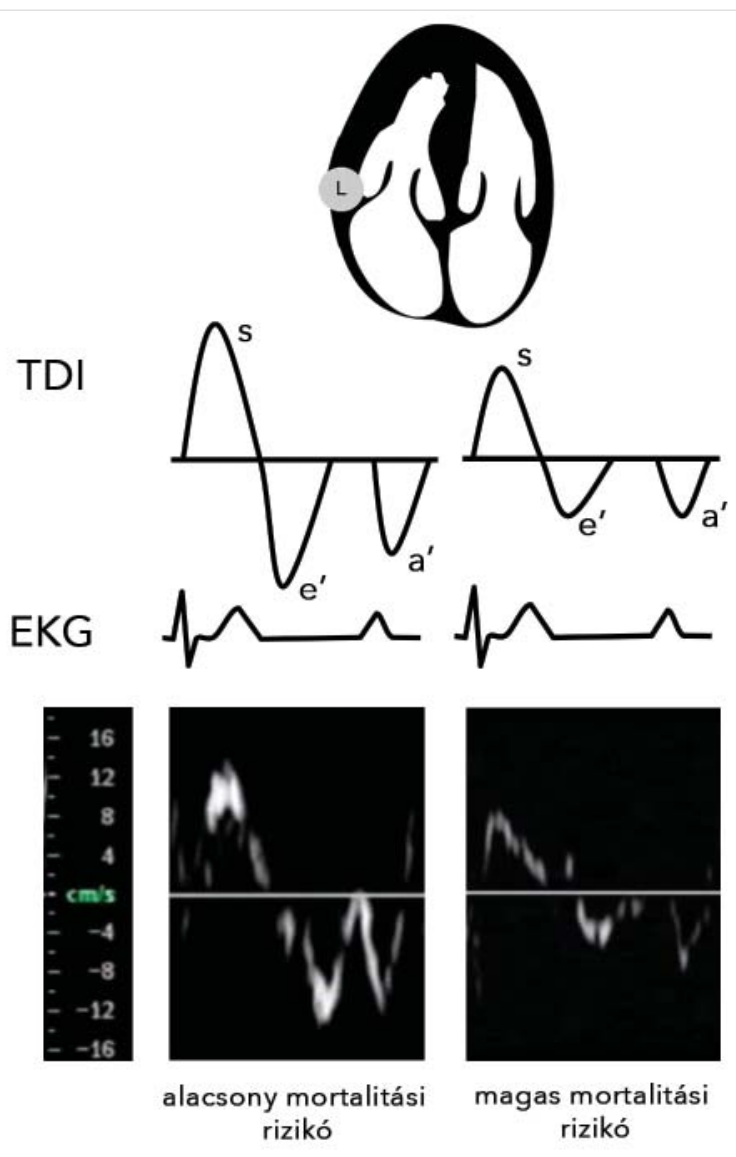

2. ÁBRA. A laterális mitralis anuluson szöveti Doppler-technikával mért koradiasztolés sebesség ( $e^{\prime}$ ) alkalmas lehet a HCM prognózisának becslésére. A laterális mitralis anulust $\mathrm{L}$ betűvel jelöltük 
megtartott ejekciós frakcióval járó szívelégtelenség diagnosztikájában alkalmazott módszer. HCM-es populációban is leírták e két biomarker szintjének jelentős emelkedését (17-20). Geske és munkatársai egy nagy esetszámú vizsgálatban arra a megállapításra jutottak, hogy az emelkedett BNP-szint a mortalitás független prediktora HCM-ban (21). Az általunk vizsgált betegek többségében emelkedett NT-proBNP-szintet találtunk és egyértelmü összefüggést fedeztünk fel a halálozás és az emelkedett NT-proBNP-szint között, ám többszörös Cox-regressziós analízisben ez a paraméter nem bizonyult a halálozás független prediktorának. Ez egybevág Maron és munkatársainak tapasztalatával, akik korlátozottnak ítélték a BNP, mint biomarker diagnosztikus erejét HCM talaján kialakuló szívelégtelenségben, mivel meglehetősen nagy átfedést találtak a különböző funkcionális osztályú betegek BNP-értékei között. Ezen kívül számos faktor, például a maximális falvastagság és az életkor zavaró mértékben befolyásolták az egyes betegek BNP-értékeit (14).

\section{Limitációk}

Munkánk elsődleges limitációja a kis esetszám. Mivel a halál oka több betegben ismeretlen maradt, nem volt módunkban a kardiovaszkuláris, illetve ezen belül a szívelégtelenség vagy aritmia-eredetü halálozás vizsgálata.

Bár feltételezhető, hogy a HCM kezelése befolyásolhatja a mortalitást, tanulmányunkban nem vizsgáltuk ezt a kapcsolatot, mivel a betegek által szedett gyógyszerekről csak részlegesen álltak rendelkezésünkre adatok.

A legfrissebb kutatások alátámasztják, hogy a szív MR-vizsgálat során észlelt késői gadolínium-halmozódás kapcsolatban áll a bal kamrai diasztolés diszfunkcióval, illetve növeli a malignus kamrai ritmuszavarok kialakulásának valószínüségét HCM-ben (22-24). Az általunk vizsgált HCM-es betegek egy részében sajnos nem állt rendelkezésre gadolínium-kontrasztanyag halmozásos MR-eredmény, így e paraméter prediktív szerepét jelen munkánkban nem tudtuk vizsgálni.

\section{Következtetések}

A diasztolés funkciózavar vizsgálata kulcsfontosságú HCM-es betegek nyomonkövetése során, hiszen ebben a kórképben a halálozás jelentős része megtartott ejekciós frakciójú szívelégtelenség talaján következik be. Bár a bemutatott számos limitáló tényező óvatosságra int eredményeink értékelésekor, azok arra utalnak, hogy a laterális mitralis anuluson mért longitudinális koradiasztolés sebesség robosztus paraméter a betegség progressziójának monitorozására és a prognózis meghatározására HCM-ben. Érdemes lehet tehát a pulzatilis szöveti Doppler-méréseket beépítenünk a követéses vizsgálatok protokolljába ebben a populációban.
Irodalom

1. Wigle ED, Rakowski H, Kimball BP, et al. Hypertrophic cardiomyopathy - Clinical spectrum and treatment. Circulation 1995; 92: 1680-92. Doi 10.1161/01.CIR.92.7.1680

2. Maron BJ, Gardin JM, Flack JM, et al. Prevalence of hypertrophic cardiomyopathy in a general population of young adults. Circulation 1995; 92: 785-9. Doi 10.1161/01 CIR.92.4.785

3. Elliott PM, Anastasakis A, Borger MA, et al. 2014 ESC Guidelines on diagnosis and management of hypertrophic cardiomyopathy. Eur Heart J 2014; 35: 2733-79. Doi 10.1093/eurheartj/ehu284

4. Maron BJ, Ommen SR, Semsarian C, et al. Hypertrophic cardiomyopathy: present and future, with translation into contemporary cardiovascular medicine. J Am Coll Cardiol 2014; 64: 83-99. Doi 10.1016/j.jacc.2014.05.003 5. Gersh BJ, Maron BJ, Bonow RO, et al. 2011 ACCF/AHA guideline for the diagnosis and treatment of hypertrophic cardiomyopathy: executive summary. Circulation 2011; 124: 2761-96. Doi 10.1161/CIR.0b013e318223e230 6. Lang RM, Badano LP, Mor-Avi V, et al. Recommendations for cardiac chamber quantification by echocardiography in adults: an update from the

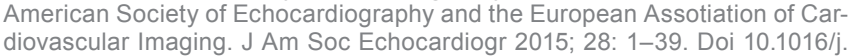
diovascular Imagin

7. Piotrowski G, Goch A, Wlazlowski R, et al. Non-invasive methods of atrial function evaluation in heart diseases. Med Sci Monit 2000; 6: 827-39

8. Nagueh SF, Smiseth OA, Appleton $\mathrm{CP}$, et al. Recommendations for the evaluation of left ventricular diastolic function by echocardiography: an update from the American Society of Echocardiography and the European Association of Cardiovascular Imaqing. J Am Soc Echocardiogr 2016; 29: 227-314. Doi $10.1016 /$ j.echo.2016.01.011

9. Nagueh SF, Bachinski LL, Meyer D, et al. Tissue Doppler imaging consistently detects myocardial abnormalities in patients with hypertrophic cardiomyopathy and provides a novel means for an early diagnosis before and independently of hypertrophy. Circulation 2001; 104: 128-30. Doi 10.1161/01.CIR.104.2.128 10. Ho CY, Sweitzer NK, McDonough B, et a

function with Doppler tissue imaging to predict genotype in preclinical hypertrophic cardiomyopathy. Circulation 2002; 105: 2992-7. Doi 10.1161/01. CIR.0000019070.70491.6D

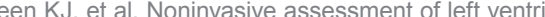
cular diastolic function by pulsed Doppler echocardiography in patients with hypertrophic cardiomvopathy. J Am Coll Cardiol 1987; 10: 733-42. Doi 10.1016/ S0735-1097(87)80264-4

Kitaoka H, Kubo T, Kayo Hayashi, et al. Tissue Doppler imaging and prognosis in asymptomatic or mildly symptomatic patients with hypertrophic cardiomvopathy. Eur Heart J Cardiovasc Imaging 2012; 14: 544-9. Doi 10.1093/ ehjci/jes200

13. McMahon CJ, Nagueh SF, Pignatelli RH, et al. Characterization of left ventricular diastolic function by tissue Doppler imaging and clinical status in child ren with hypertrophic cardiomvopathy. Circulation 2004; 109: 1756-62. Doi 10.1161/01.CIR.0000124723.16433.31

14. Nagueh SF, Lakkis NM, Middleton KJ, et al. Doppler estimation of left ventricular filling pressures in patients with hypertrophic cardiomyopathy. Circulation 1999; 99: 254-61. Doi 10.1161/01.CIR.99.2.254

15. Cardim N, Oliveria AG, Longo S, et al. Doppler tissue imaging: Regional myocardial function in hypertrophic cardiomyopathy and in athlete's heart. J Am Soc Echocardiogr 2003; 16: 223-32. Doi 10.1067/mje.2003.13 16. Maron BJ, Wolfson J, Roberts W. Relation between extent of cardiac muscle cell disorganization and left ventricular wall thickness in hypertrophic cardiomyopathy. Am J Cardiol 1992; 70: 785-90. Doi 10.1016/0002 9149(92)90560-L

17. Brigouri C, Betocchi S, Manganelli F, et al. Determinants and clinical significance of natriuretic peptides in hypertrophic cardiomyopathy. Eur Heart 2001; 22: 1328-36. Doi 10.1053/euhj.2000.2535

18. Maron BJ, Tholakanahalli VN, Zenovich AG, et al. Usefulness of B-type natriuretic peptide assay in the assessment of symptomatic state in hypertrophic cardiomyopathy. Circulation 2004; 109: 984-9. Doi 10.1161/01.

\section{CIR.0000117098.75727.D8}

T. Cambronén V, et al. Biomarkers of pathophysiology in hypertrophic cardiomyopathy: implications for clinical management and prog nosis. Eur Heart J 2009; 30: 139-51. Doi 10.1093/eurheartj/ehn538

20. Faludi $R$, Tóth $L$, Pótó $L$, et al. A B típusú natriureticus peptid (NT-proBNP) szint és a diastolés funkciót jellemző hagyományos és szöveti Doppler-echokardiográfiás paraméterek kapcsolata hypertrophiás cardiomyopathiában szenvedö betegekben. Orv Hetil 2005; 146: 23-6.

21. Geske JB, McKie PM, Ommen SR, et al. B-type natriuretic peptide and survival in hypertrophic cardiomyopathy. J Am Coll Cardiol 2013; 61: 2456 60. Doi 10.1016/j.jacc.2013.04.004

22. Green JJ, Berger JS, Kramer CM, et al. Prognostic value of late gadolinium enhancement in clinical outcomes for hypertrophic cardiomyopathy. JACC Cardiovasc Imaging 2012; 5: 370-7. Doi 10.1016/j.jcmg.2011.11.021 23. Rickers C, Wilke NM, Jerosch-Herold M, ef al. Utility of cardiac magnetic resonance imaging in the diagnosis of hypertrophic cardiomyopathy. Circulation 2005; 112: 855-61. Doi 10.1161/CIRCULATIONAHA.104.507723 24. Bruder $O$, Wagner A, Jensen CJ, et al. Myocardial scar visualized by cardiovascular magnetic resonance imaging predicts major adverse events in patients with hypertrophic cardiomyopathy. J Am Coll Cardiol 2010; 56: 87587. Doi $10.1016 /$ j.jacc. 2010.05 .007 